\title{
Identifikasi Sebaran dan Karakter Tanaman Leci sebagai Tanaman Lansekap di Tepi Jalan Raya Payangan, Kecamatan Payangan, Kabupaten Gianyar
}

\author{
I WAYAN SAPTAYANA ${ }^{1}$, A.A. GEDE DALEM SUDARSANA ${ }^{1 *}$, \\ I MADE SUKEWIJAYA ${ }^{2}$
}

1. Program Studi Arsitektur Pertamanan, Fakultas Pertanian, Universitas Udayana, JI. PB. Sudirman, Denpasar 80225 Indonesia

2. Program Studi Agroekoteknologi, Fakultas Pertanian, Universitas Udayana, JI. PB. Sudirman, Denpasar 80225 Indonesia

*E-mail: agungdalems@gmail.com

\begin{abstract}
The Identification of Distribution and The Character of Lychee as The Landscape Plant in Sides of The Jalan Raya Payangan, The District of Payangan, Gianyar Regency
\end{abstract}

Lychee plants in Bali are plants that introduced from China, that is comes from Guangdong and Fujian. Although this plant is not as an original plant from Indonesia and classified as rare plant, however it has been established as flora of the identity of Gianyar Regency. Lychee plant is one of the many types of trees that grown along to Jalan Raya Payangan. However, nowadays, its existence has been reduced. This study aims to find out the distribution and appropriateness of the character of lychee as landscape plants in Payangan, Gianyar Regency. This research was using survey method with data collection technique, by field observation, interview, questionnaires and literature study. The final result of research shows that $14,5 \mathrm{~km}$ in Jalan Raya Payangan, there are 18 species of plants as framer of landscape in Payangan. There are 42 lychee plants that still growing properly and there are five filling formers of lychee trees. Based on the combination of the technical reference Direktorat Jendral Bina Marga (1996), Steenis (2005), and Carpenter, (2000), there are nine terms of plants that required being landscape plant on sides of the roads, but from nine terms the research founded that lychee plants only requiring five terms, about that lychee plants unfit as landscape plant on sides of the Jalan Raya Payangan, The District of Payangan, Gianyar Regency.

Keywords: lychee plant, character, landscape plants, Payangan, Gianyar. 


\section{Pendahuluan}

\subsection{Latar Belakang}

Tanaman leci yang ada di Bali merupakan tanaman yang diintroduksi dari Cina, tepatnya berasal dari wilayah Guangdong dan Fujian. Walupun tanaman leci bukan sebagai tanaman asli Indonesia dan tergolong tanaman langka, sejak tanggal 13 Oktober 2014 berdasarkan keputusan DPRD Kabupaten Gianyar nomor 18 tahun 2014, tanaman leci diusulkan dan ditetapkan sebagai flora identitas Kabupaten Gianyar (Dprdgianyarkab.go.id, 2015). Sebaran tanaman leci yang ada di Kabupaten Gianyar terdapat di Kecamatan Tegalalang, Tampaksiring, Ubud dan terbanyak di Kecamatan Payangan. Keberadaan tanaman leci di sepanjang Jalan Raya Payangan dari tahun ke tahun jumlahnya semakin berkurang, dari sekitar 1000 pohon leci yang ada sejak 150 tahun yang lampau hanya sekitar 300 pohon yang tersisa saat ini (Runa, 2015). Kondisi tersebut disebabkan karena tanaman leci tidak produktif lagi untuk menghasilkan buah, program listrik masuk desa, gangguan akar tanaman leci yang merusak bangunan penduduk, dan banyak ditebang untuk kemudian dibangun kios-kios atau toko.

Menurut Direktorat Jendral Bina Marga (1996), lansekap jalan adalah wajah dari karakter lahan atau tapak yang terbentuk dari lingkungan jalan, baik yang terbentuk dari elemen lansekap alamiah seperti bentuk topografi lahan yang mempunyai panorama yang indah, maupun yang terbentuk dari elemen lansekap buatan manusia yang disesuaikan dengan kondisi lahannya.

Tanaman jenis pohon merupakan salah satu elemen lansekap jalan yang memiliki nilai fungsional dan estetika. Secara fungsional, tanaman lansekap dapat berfungsi untuk mengontrol pandangan, berfungsi sebagai penghalang, dan peneduh jalan (Carpenter et al., 2000). Tanaman leci adalah salah satu jenis tanaman pohon yang merupakan identitas flora Kabupaten Gianyar dan banyak tumbuh di sepanjang Jalan Raya Payangan, namun saat ini keberadaannya sudah mulai berkurang. Oleh karena itu, perlu dilakukan kajian mengenai sebaran dan kesesuaian karakter tanaman leci sebagai tanaman lansekap di tepi Jalan Raya Payangan, Kecamatan Payangan, Kabupaten Gianyar. Rumusan masalah penelitian ini antara lain 1) Bagaimana sebaran tanaman leci di sepanjang Jalan Raya Payangan?; dan 2) Bagaimana kesesuaian karakter tanaman leci sebagai tanaman lansekap tepi jalan sepanjang Jalan Raya Payangan?. Sedangkan tujuan dari penelitian ini yaitu 1) untuk memetakan sebaran tanaman leci di sepanjang Jalan Raya Payangan dan 2) mengetahui kesesuaian karakter tanaman leci sebagai tanaman lansekap tepi jalan sepanjang Jalan Raya Payangan berdasarkan kecepatan tumbuh, ukuran dimensi tajuk, ketahanan pohon terhadap penyakit, dan pemeliharaan. Manfaat yang diperoleh dari penelitian ini antara lain memberi informasi sebaran tanaman leci yang masih ditemukan di sepanjang Jalan Raya Payangan, merekomendasikan kesesuaian karakter tanaman leci sebagai tanaman lansekap jalan di sepanjang Jalan Raya Payangan, serta menjaga kelestarian plasma nutfah tanaman leci yang merupakan flora identitas Kabupaten Gianyar. 


\section{Metode}

\subsection{Waktu dan Tempat Penelitian}

Penelitian dilaksanakan di kawasan Jalan Raya Payangan, Kecamatan Payangan, Kabupaten Gianyar yang secara administratif termasuk ke dalam wilayah Desa Melinggih Kelod, Desa Melinggih, Desa Puhu dan Desa Kerta. Penelitian berlangsung selama tiga bulan dimulai dari bulan Oktober sampai dengan bulan Desember 2016

\subsection{Alat Penelitian}

Alat yang digunakan dalam penelitian ini adalah: kamera digital, GPS, alat perekam suara, komputer, lembar wawancara dan lembar kuesioner.

\subsection{Metode Penelitian}

Penelitian ini menggunakan metode survei dengan teknik pengumpulan data, melalui observasi lapangan, wawancara, penyebaran kuesioner dan studi pustaka di kawasan Jalan Raya Payangan Kecamatan Payangan Kabupaten Gianyar yang memiliki panjang $14,5 \mathrm{~km}$.

\subsubsection{Jenis Data}

Data yang dikumpulkan dalam penelitian ini berupa data primer dan data sekunder. Data primer diperoleh melalui hasil pengamatan langsung di lapangan dengan melakukan observasi, menyebarkan kuesioner, dan melakukan wawancara dengan pihak terkait. Data sekunder mencakup studi pustaka yang bersumber dari buku-buku, jurnal dan internet maupun dokumen pemerintah yang berisi informasi tata ruang di wilayah penelitian.

\subsubsection{Teknik Pengumpulan Data}

Dalam penelitian ini data dikumpulkan melalui beberapa cara yaitu:

\section{Observasi lapangan}

Observasi dalam penelitian ini dilakukan pengamatan secara langsung kondisi tapak untuk mengetahui data informasi digital sebaran tanaman leci dan kondisi tanaman leci di sepanjang Jalan Raya Payangan.

2. Kuesioner

Kuesioner dilakukan dengan memberikan angket atau daftar pertanyaan kepada responden. Jenis kuesioner yang digunakan dalam penelitian ini adalah kuesioner tertutup. Kuesioner ditujukan kepada masyarakat yang bermukim di sekitar Jalan Raya Payangan dan pengguna Jalan Raya Payangan dengan pertanyaan terkait keberadaan tanaman leci, sejarah tanaman leci, kesesuaian tanaman leci sebagai tanaman lansekap tepi jalan, dan pengaruh tanaman leci terhadap pengguna Jalan Raya Payangan.

3. Wawancara

Wawancara dilakukan untuk memperoleh informasi dengan mengadakan tanya jawab langsung kepada pihak-pihak terkait secara mendalam (in-depth interview). Informasi mengenai sejarah tanaman leci, usia tanaman leci, dan prilaku masyarakat dalam penggunaan lahan untuk meningkatkan perekonomian diperoleh dari masyarakat yang bermukim di sepanjang Jalan Raya Payangan. Informasi mengenai keberadaan tanaman 
leci yang banyak ditanam di pinggir jalan dan jumlahnya semakin berkurang diperoleh melalui wawancara dengan pemangku kepentingan seperti bendesa adat, kepala desa, dan Camat Payangan.

4. Studi pustaka

Studi pustaka yaitu mencari data yang berhubungan dengan penelitian ini baik di peroleh dari jurnal hasil penelitian, buku-buku ilmiah, laporan penelitian, peraturanperaturan, ketetapan-ketetapan, dan sumber-sumber tertulis maupun media elektronik (internet).

\subsection{Tahapan Penelitian}

Penelitian ini terdiri dari beberapa tahapan yang dilakukan meliputi tahap inventarisasi, analisis, dan sintesis.

\subsubsection{Inventarisasi}

Tahap inventarisasi dilakukan dengan melihat kondisi lansekap jalan yaitu dilihat dari aspek biofisik dan aspek sosial-ekonomi. Aspek biofisik meliputi pola penggunaan lahan pada kawasan tapak pengamatan, dan inventarisasi terhadap sebaran vegetasi tanaman leci dan jenis tanaman tepi jalan lainnya. Aspek sosial-ekonomi meliputi demografi Kecamatan Payangan dan usaha prilaku masyarakat untuk meningkatkan perekonomian.

\subsubsection{Analisis}

Metode analisis data menurut Silalahi (2006) meliputi tahap pengolahan data hasil observasi, kuesioner, dan wawancara. Pendekatan analisis yang digunakan adalah dengan metode analisis tabulasi, spasial, dan deskriptif.

1. Tabulasi

Metode pengolahan data yang digunakan dalam mengolah data hasil kuesioner dalam penelitian ini adalah tabulasi data dalam bentuk persentase (\%). Menurut Sudjana (2001), teknik tabulasi data ini digunakan untuk menghitung jumlah pilihan responden (f) dibandingkan dengan jumlah keseluruhan responden $(\mathrm{N})$ ke dalam bentuk persentase (\%) dengan dikali 100 persen. Perhitungan persentase seperti dikemukakan Sudjana (2001), adalah sebagai berikut:

$$
P=f / N \times 100 \%
$$

keterangan: $P=$ Persentase

$$
\begin{aligned}
& f=\text { Frekuensi } \\
& N=\Sigma \text { Total responden }
\end{aligned}
$$

\section{Analisis spasial}

Analisis spasial dilakukan bertujuan untuk memetakan keberadaan tanaman leci, untuk mengetahui sebarannya. Menyiapkan peta dasar, tahap pada format peta digital yaitu dengan menginput sumber data sekunder. Apabila sumber data tersebut dengan format raster (JPEG), maka perlu diubah menjadi format digital dengan melakukan on screen digitation. Perlu dilakukan proses koreksi geometrik dengan melakukan rektifikasi. Setelah peta dasar siap, tahap selanjutnya adalah menginput data hasil pengukuran di lapangan, dalam penelitian ini adalah data yang berasal dari GPS. Titik-titik GPS akan menginformasikan sebaran keberadaan tanaman leci yang terdapat di sepanjang Jalan Raya Payangan. 


\section{Analisis Deskriptif}

Analisis deskriptif adalah metode yang digunakan untuk menganalisis data dengan cara mendeskripsikan atau menggambarkan data yang telah terkumpul tanpa bermaksud membuat kesimpulan yang berlaku untuk umum (Sugiyono, 2004).

\subsubsection{Sintesis}

Tahap sintesis merupakan tahapan pemecahan masalah dari obyek penelitian berdasarkan hasil analisis data dengan metode tabulasi, analisis spasial, dan analisis deskriptif. Tujuan sintesis adalah untuk mengetahui sebaran dan kesesuaian karakter tanaman leci sebagai tanaman lansekap jalan di Jalan Raya Payangan, Kecamatan Payangan, Kabupaten Gianyar.

\subsection{Batasan Penelitian}

Penelitian ini dilakukan terbatas pada lansekap jalan yang melintasi empat desa dalam wilayah administrasi Kecamatan Payangan, Kabupaten Gianyar, Provinsi Bali. Tahap studi dilakukan dengan melakukan inventarisasi, analisis dan sintesis pada tapak.

\section{Hasil dan Pembahasan}

\subsection{Elemen Tanaman Pembentuk Lansekap Jalan Raya Payangan}

Berdasarkan survei yang dilakukan pada Jalan Raya Payangan Kecamatan Payangan Kabupaten Gianyar sepanjang 14,5 km, yang secara administratif termasuk ke dalam wilayah Desa Melinggih Kelod, Desa Melinggih, Desa Puhu, dan Desa Kerta ditemukan sebanyak 18 jenis tanaman peneduh pembentuk lansekap Jalan Raya Payangan dengan jumlah keseluruhan 1033 pohon, disajikan pada Tabel 1.

Tabel 1. Jumlah Elemen Tanaman Peneduh Pembentuk Lansekap Jalan Raya Payangan

\begin{tabular}{|c|c|c|c|c|c|c|c|}
\hline \multirow{3}{*}{ No } & \multirow{3}{*}{ Nama Tanaman } & \multicolumn{4}{|c|}{ Jalan Raya Payangan } & \multirow{3}{*}{ Total } & \multirow{3}{*}{$\begin{array}{c}\text { Persentase } \\
(\%)\end{array}$} \\
\hline & & Desa & Desa & Desa & Desa & & \\
\hline & & & & PHU & KRT & & \\
\hline 1 & Glodogan tiang (Polyathea longifolia) & 30 & 78 & 169 & 27 & 304 & $29,42 \%$ \\
\hline 2 & Tanjung (Mimusops elengi) & 23 & 75 & 255 & 110 & 463 & $44,82 \%$ \\
\hline 3 & Cempaka (Michelia champaca) & 55 & 13 & 22 & 14 & 104 & $10,1 \%$ \\
\hline 4 & Mahoni (Switenia mahagoni) & 0 & 0 & 0 & 43 & 43 & $4,16 \%$ \\
\hline 5 & Leci (Litchi chinensis Sonn.) & 6 & 11 & 8 & 17 & 42 & $4,06 \%$ \\
\hline 6 & Waru (Hibiscus tiliaceus) & 2 & 5 & 6 & 2 & 15 & $1,45 \%$ \\
\hline 7 & Nangka (Artocarpus heterophylla) & 0 & 3 & 11 & 0 & 14 & $1,35 \%$ \\
\hline 8 & Palem putri (Veitchia merrilli) & 2 & 5 & 0 & 0 & 7 & $0,67 \%$ \\
\hline 9 & Mangga (Mangifera indica) & 0 & 4 & 0 & 3 & 7 & $0,67 \%$ \\
\hline 10 & Ketapang (Terminalia cattapa) & 0 & 2 & 2 & 0 & 4 & $0,39 \%$ \\
\hline 11 & Bunga kupu-kupu (Bauhinia purpurea) & 0 & 0 & 3 & 0 & 3 & $0,29 \%$ \\
\hline 12 & Sikat botol (Callistemon lanceolatus) & 3 & 0 & 0 & 0 & 3 & $0,29 \%$ \\
\hline 13 & Sawo kecik (Manilkara kauki) & 0 & 4 & 0 & 0 & 4 & $0,39 \%$ \\
\hline 14 & Kere payung (Filicium decipiens) & 0 & 1 & 0 & 0 & 1 & $0,1 \%$ \\
\hline 15 & Kersen (Muntingia calabura L.) & 0 & 4 & 2 & 0 & 6 & $0,58 \%$ \\
\hline
\end{tabular}




\begin{tabular}{|c|c|c|c|c|c|c|c|}
\hline \multirow[b]{2}{*}{ No } & \multirow[b]{2}{*}{ Nama Tanaman } & \multicolumn{4}{|c|}{ Jalan Raya Payangan } & \multirow[b]{2}{*}{ Total } & \multirow{2}{*}{$\begin{array}{c}\text { Persentase } \\
(\%)\end{array}$} \\
\hline & & $\begin{array}{l}\text { Desa } \\
\text { MLK }\end{array}$ & $\begin{array}{l}\text { Desa } \\
\text { MLG }\end{array}$ & $\begin{array}{l}\text { Desa } \\
\text { PHU }\end{array}$ & $\begin{array}{l}\text { Desa } \\
\text { KRT }\end{array}$ & & \\
\hline 16 & $\begin{array}{l}\text { Bunga kecrutan (Spathodea } \\
\text { campanulata) }\end{array}$ & 0 & 3 & 0 & 0 & 3 & $0,29 \%$ \\
\hline 17 & Sirsak (Annona muricata) & 0 & 0 & 6 & 0 & 6 & $0,58 \%$ \\
\hline 18 & Pohon bodhi (Ficus religiosa) & 2 & 1 & 1 & 0 & 4 & $0,39 \%$ \\
\hline & Jumlah & 123 & 209 & 485 & 216 & 1033 & \\
\hline & Persentase (\%) & $12 \%$ & $\begin{array}{l}20 \\
\%\end{array}$ & $\begin{array}{l}47 \\
\%\end{array}$ & $\begin{array}{l}21 \\
\%\end{array}$ & $100 \%$ & $100 \%$ \\
\hline
\end{tabular}

Keterangan: MLK= Melinggih Kelod, MLG= Melinggih, PHU= Puhu, KRT= Kerta

Jenis tanaman yang ditanam tersebar di empat desa yaitu sebanyak $12 \%$ dari total jumlah tanaman terdapat di Desa Melinggih Kelod, 20\% di Desa Melinggih, 47\% di Desa Puhu dan 21\% terdapat di Desa Kerta. Sebagian besar tanaman terdapat di Desa Puhu karena jarak Jalan Raya Payangan wilayah Desa Puhu merupakan wilayah terpanjang yaitu mencapai $6 \mathrm{~km}$, selain itu Jalan Raya Payangan di wilayah Desa Puhu belum banyak terjadi pemanfaatan ruang yang terbangun oleh penduduk, sebagian besar lahan yang terdapat dimanfaatkan sebagai lahan pertanian dan perkebunan sehingga tanaman yang terdapat di sepanjang jalan masih tetap terjaga dan tidak diganggu keberadaannya oleh masyarakat di sekitar jalan wilayah Desa Puhu. Jalan Raya Payangan di wilayah Desa Melinggih Kelod merupakan lingkup wilayah terpendek dari total pajang Jalan Raya Payangan yaitu dengan jarak 1,6 km, selain itu Jalan Raya Payangan di wilayah Desa Melinggih Kelod banyak terjadi pemanfaat ruang terbangun oleh masyarakat. Adanya pemanfaatan ruang terbangun seperti kios-kios atau toko sehingga dapat mengganggu keberadaan tanaman yang terdapat di sepanjang jalan di wilayah Desa Melinggih Kelod, masyarakat mulai menebang tanaman yang terdapat di sepanjang jalan karena dianggap menghalangi kios-kios atau tokonya.

Persentase tanaman leci sebagai elemen pembentuk lansekap Jalan Raya Payangan dari keempat wilayah desa yang dilalui jalur Jalan Raya Payangan yaitu sebanyak $4,06 \%$ dari total jumlah tanaman yang ada. Jenis tanaman yang banyak terdapat di Jalan Raya Payangan adalah tanaman glodogan tiang sebanyak $29,42 \%$ dan tanjung sebanyak $44,82 \%$, tanaman ini banyak terdapat di sepanjang Jalan Raya Payangan karena merupakan program dari pemerintah daerah dalam penghijauan sebagai tanaman perindang jalan.

\subsection{Sebaran dan Pengaruh Tanaman Leci terhadap Pengguna Jalan Raya Payangan}

Berdasarkan hasil survei yang dilakukan terhadap keberadaan titik sebaran tanaman leci yang terdapat di sepanjang Jalan Raya Payangan, saat ini ditemukan sebanyak 42 pohon leci yang masih tumbuh dengan baik dan lima bekas tebangan pohon leci, dapat dilihat pada Gambar 1. 


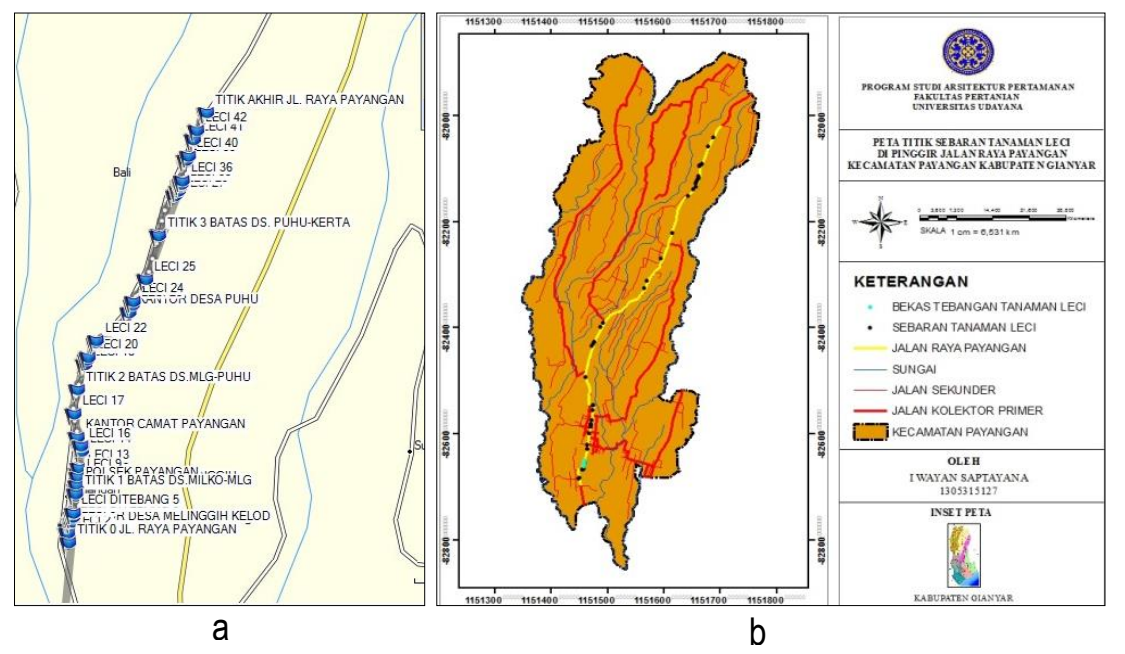

Gambar 1. Titik Sebaran Tanaman Leci di Sepanjang Jalan Raya Payangan

(a) Hasil Pengukuran GPS (b) Hasil Pengolahan ArcGIS

(b)

Sebaran tanaman leci yang terdapat di sepanjang Jalan Raya Payangan dapat ditemui di setiap wilayah desa yang dilalui Jalan Raya Payangan. Jumlah sebaran tanaman leci yang terdapat di sepanjang Jalan Raya Payangan wilayah Desa Kerta sebanyak 17 pohon, wilayah Desa Puhu sebanyak 8 pohon, wilayah Desa Melinggih sebanyak 11 pohon dan wilayah Desa Melinggih Kelod sebanyak 6 pohon leci yang masih tumbuh dengan baik dan 5 bekas tebangan pohon leci. Tanggapan masyarakat yang bermukim di sekitar Jalan Raya Payangan dan pengguna Jalan Raya Payangan mengenai keberadaan, sejarah, dan pengaruh tanaman leci terhadap pengguna Jalan Raya Payangan, Kecamatan Payangan, Kabupaten Gianyar. Sebanyak 94\% masyarakat berasal dari Kecamatan Payangan lahir di Payangan, 3\% berasal dari luar Kecamatan Payangan masih wilayah Kabupaten Gianyar, dan 3\% berasal dari luar Kabupaten Gianyar. Sebanyak $97 \%$ masyarakat lama tinggal di Kecamatan Payangan dan melewati atau memakai jalur Jalan Raya Payangan lebih dari 15 tahun dan sebanyak 3\% masyarakat lama tinggal di Kecamatan Payangan dan melewati atau memakai jalur Jalan Raya Payangan yaitu 11 - 15 tahun.

Pemerintah daerah telah menetapkan tanaman leci sebagai flora identitas Kabupaten Gianyar untuk menjaga kelestarian tanaman leci. Hasil penelitian menunjukkan sebanyak $20 \%$ masyarakat sangat tahu, $37 \%$ tahu, $20 \%$ kurang tahu dan $23 \%$ tidak tahu mengenai tanaman leci sebagai flora identitas Kabupaten Gianyar. Sebagian besar masyarakat yang tahu tanaman leci sebagai flora identitas Kabupaten Gianyar mendapatkan informasi dari instansi sekolah dan tempat kerja, hal tersebut diakibatkan karena pemerintah daerah Kabupaten Gianyar dalam mensosialisasikan tanaman leci sebagai flora identitas Kabupaten Gianyar lebih mengarah instasi pemerintahan dibandingkan masyarakat banyak. Seiring perkembangan jaman yang mengakibatkan meningkatnya kebutuhan masyarakat terhadap ruang keberadaan tanaman leci yang terdapat di sepanjang jalur Jalan Raya Payangan semakin berkurang. Hasil penelitian menunjukkan sebanyak $70 \%$ masyarakat sangat tahu, dan 30\% tahu bahwa tanaman leci semakin berkurang.

Tanaman leci yang ada di Kecamatan Payangan merupakan tanaman yang dibawa langsung oleh pedagang dari Cina yang bernama Lee Tong melalui pengenalan regulasi perekonomian sistem perdagangan. Hasil peneltian menunjukkan sebanyak $6 \%$ masyarakat sangat tahu, $20 \%$ tahu, 30\% kurang tahu dan $44 \%$ tidak tahu mengenai sejarah tanaman leci yang ada di Kecamatan Payangan. Tanaman leci yang ada di Kecamatan Payangan sebagian besar terdapat di pinggir 
jalan, hasil penelitian menunjukkan sebanyak $20 \%$ masyarakat sangat setuju, $60 \%$ setuju, $6 \%$ kurang setuju, dan $14 \%$ tidak setuju bahwa tanaman leci sebagai tanaman lansekap tepi jalan.

Tanggapan masyarakat mengenai manfaat dari tanaman leci sebagai tanaman lansekap tepi jalan sebanyak $14 \%$ sangat baik dan $60 \%$ baik, masyarakat merasakan manfaat dari tanaman karena tanaman leci memiliki struktur percabangan yang banyak dan kuat serta tajuk yang indah sehingga dapat meneduhi pengguna jalan. Keberadaan tanaman leci yang ada di pinggir Jalan Raya Payangan dapat mempengaruhi pengguna jalan. Hasil penelitian menunjukkan sebanyak $6 \%$ tanaman leci mengganggu pengguna jalan, 20\% cukup mengganggu, dan $74 \%$ tidak mengganggu pengguna jalan. Tanggapan masyarakat yang menarik dari tanaman leci sebanyak $27 \%$ menjawab akar, sebanyak $10 \%$ menjawab tajuk dan $63 \%$ menjawab buah. Sebagian besar masyarakat mengatakan buah yang menarik dari tanaman leci karena buah leci dapat dimakan. Berdasarkan penelitian Peni (2015) leci mengandung sukrosa dan glukosa melimpah. Kandungan gula yang terdapat dalam buah leci mencapai 10 sampai 13 persen. Leci juga merupakan sumber serat pangan (dietary fiber) yaitu sekitar 1,3 gram per 100 gram daging buah. Vitami yang paling menonjol pada buah leci adalah vitamin $\mathrm{C}$ dengan kadar 71,5 mg per 100 gram daging buah.

Tanaman leci dapat tumbuh dengan baik di Kecamatan Payangan, dan tanggapan masyarakat mengenai tempat yang cocok untuk menanam tanaman leci yaitu sebanyak $20 \%$ di pinggir jalan, $60 \%$ pojok lapangan, $14 \%$ tegalan dan $6 \%$ di ladang. Sebagian besar masyarakat mengatakan tempat yang cocok untuk menanam tanaman leci yaitu di pojok lapangan karena tempat tersebut merupakan tempat yang paling strategis dibandingkan dengan tempat yang lain. Melihat struktur yang dimiliki tanaman leci yaitu dengan sistem perakaran kokoh, batang besar, percabangan banyak dan kuat, serta tajuk yang lebar, keberadaan tanaman leci jika ditanam di pojok lapangan tidak dapat mengganggu aktivitas manusia, bangunan rumah, maupun tanaman lainnya.

\subsection{Kesesuaian Karakter Tanaman Leci sebagai Tanaman Lansekap Tepi Jalan}

Acuan yang digunakan dalam penentuan jenis tanaman untuk lansekap jalan sebagaimana yang termuat dalam petunjuk teknis Direktorat Jenderal Bina Marga No.033/T/BM/1996, syarat tanaman peneduh jalan menurut Steenis (2005), dan pemilihan tanaman pohon untuk lansekap tepi jalan menurut Carpenter (2000). Syarat tanaman untuk lansekap jalan ada sembilan, yaitu perakaran yang tidak merusak struktur bangunan jalan, batang dan percabangan yang tidak mudah patah, daun tidak mudah rontok, kecepatan tumbuh sedang hingga cepat, buahnya tidak terlalu besar, ukuran diameter tajuk terhadap lebar jalan, ketersediaan ruang untuk menanam, ketahanan pohon terhadap hama dan penyakit, serta pemeliharaan yang relatif mudah dan murah. Berdasarkan persyaratan tersebut tanaman leci hanya memenuhi lima persyaratan dilihat dari tanaman leci memiliki daun yang tidak mudah rontok dengan persentase $60 \%$, buahnya tidak terlalu besar $70 \%$, memiliki batang dan percabangan yang kuat $60 \%$, tanaman yang tahan terhadap hama dan penyakit $47 \%$, serta pemeliharaan terhadap tanaman leci relatif mudah $60 \%$, dengan demikian tanaman leci tidak layak sebagai tanaman lansekap tepi jalan di Jalan Raya Payangan, Kecamatan Payangan Kabupaten Gianyar.

Tanaman leci yang ada di pinggir jalan sepanjang jalur Jalan Raya Payangan dapat mempengaruhi perekonomian masyarakat sekitar. Hasil penelitian menunjukkan sebanyak $47 \%$ masyarakat tidak setuju tanaman leci dapat meningkatkan perekonomian. Berdasarkan pengamatan penulis bahwa, sebagian besar masyarakat tidak setuju tanaman leci dapat meningkatkan perekonomian, karena melihat kondisi tanaman leci yang ada di sepanjang jalur Jalan Raya Payangan saat ini jarang berbuah hasilnya tidak maksimal, mengganggu jaringan kabel 
listrik dan dapat mengganggu bangunan penduduk. Tanggapan masyarakat untuk menjaga kelestarian tanaman leci, hasil penelitian menunjukkan sebanyak $60 \%$ masyarakat setuju tanaman leci perlu dilestarikan, karena leci merupakan flora identitas Kabupaten Gianyar dan sudah tergolong tanaman langka.

\subsubsection{Pengaruh karakteristik biofisik terhadap tanaman leci}

Jalan Raya Payangan, Kecamatan Payangan, Kabupaten Gianyar secara administratif termasuk ke dalam wilayah Desa Melinggih Kelod, Desa Melinggih, Desa Puhu, dan Desa Kerta. Masing-masing wilayah desa tersebut terletak pada ketinggian Desa Melinggih Kelod 300 sampai 554 meter di atas permukaan laut, Desa Melinggih 500 sampai 600 meter di atas permukaan laut, Desa Puhu 564 sampai 758 meter di atas permukaan laut, Desa Kerta 613 sampai 804 meter di atas permukaan laut, dengan luas masing-masing wilayah yaitu Desa Melinggih Kelod 4,62 km2, Desa Melinggih 4,87 km2, Desa Puhu 13,91 km2 dan Desa Kerta 14,42 km2 (Profil Kecamatan Payangan, 2015).

Kecamatan Payangan memiliki suhu yang sejuk bahkan cenderung dingin dan dikenal sebagai daerah yang subur dan cocok untuk lahan pertanian. Suhu rata-rata tahunan adalah $23,9^{\circ} \mathrm{C}$, dengan curah hujan tahunan rata-rata $2.090 \mathrm{~mm}$. Kecamatan Payangan memiliki musim hujan lebih panjang daripada musim kemarau, dengan demikian kebutuhan air untuk irigasi dan kebutuhan lainnya sangat mencukupi (Climate-data.org, 2016). Menurut Phiets (2009) leci dapat tumbuh dengan baik di daerah dataran tinggi dengan ketinggian lebih dari 700 meter di atas permukaan laut dengan suhu udara rata-rata $23^{\circ} \mathrm{C}$ dan curah hujan rata-rata $2.000 \mathrm{~mm}$ per tahun. Berdasarkan syarat tumbuh tanaman leci tersebut, keadaan biofisik Kecamatan Payangan sangat cocok dan dapat mendukung pertumbuhan tanaman leci untuk dapat dikembangkan di Kecamatan Payangan.

\subsubsection{Pengaruh karakteristik sosial ekonomi terhadap tanaman leci}

Karakter sosial ekonomi di Kecamatan Payangan khususnya pada wilayah lokasi penelitian, yaitu wilayah Desa Melinggih Kelod, Desa Melinggih, Desa Puhu dan Desa Kerta memiliki kondisi yang hampir sama. Kepemimpinan tertinggi di wilayah tersebut dipimpin seorang Kepala Desa dan dibantu oleh Kelian Dinas di masing-masing banjar. Masing-masing wilayah desa pada lokasi penelitian terdiri dari beberapa banjar yaitu Desa Melinggih Kelod enam banjar, Desa Melinggh lima banjar, Desa Puhu tujuh banjar dan Desa Kerta terdiri dari delapan banjar. Jumlah penduduk di masing-masing wilayah yaitu di Desa Melinggih Kelod 3.844 jiwa yang terdiri dari laki-laki sebanyak 1.943 jiwa dan perempuan 1.901 jiwa, Desa Melinggih 7.119 jiwa yang terdiri dari lakilaki sebanyak 3.549 jiwa dan perempuan 3.570 jiwa, Desa Puhu 5.181 jiwa yang terdiri dari laki-laki sebanyak 2.571 jiwa dan perempuan 2.610 jiwa dan Desa Kerta 4.909 jiwa yang terdiri dari laki-laki sebanyak 2.534 jiwa dan perempuan 2.375 jiwa. Penduduk pada lokasi penelitian doinan menganut agama Hindu dan sebagian besar bermata pencaharian sebagai petani. (Profil Kecamatan Payangan, 2015).

Tanaman leci di Kecamatan Payangan sudah ada sejak dahulu di jaman masa kerajaan Payangan yang dibawa oleh pedagang dari Cina persebarannya pertama ditanam di ambal-ambal puri. Melihat perkembangan tanaman leci dapat tumbuh dengan baik, kemudian untuk menjaga kelestarian tanaman leci selanjutnya tanaman leci mulai ditanam di tempat strategis seperti pasar, lapangan dan pinggir jalan. Orang yang menanam tanaman leci tersebut tidak boleh sembarangan orang, hanya orang tertentu yang dapat menanam tanaman leci seperti masyarakat yang menjadi parekan (pembantu) di puri Payangan yang boleh menanam tanaman tersebut (hasil wawancara dengan Sudarma, 2016). 
Tanaman leci di Kecamatan Payangan pernah mengalami masa jaya sekitar tahun 1970-an. Seiring perkembangan jaman dengan perubahan cuaca yang tidak menentu di Kecamatan Payangan, dan faktor usia dari tanaman leci diperkirakan mencapai 174 tahun mengakibatkan tanaman leci tidak produktif lagi menghasilkan buah, selain itu adanya gangguan kabel listrik, dan perakaran leci yang melebar dapat merusak bangunan penduduk. Sebagaian besar masyarakat yang memiliki tanaman leci mulai menebang tanaman leci untuk dijual. Kayunya dimanfaatkan sebagai bahan kerajinan dan lahan bekas tebangan dari tanaman leci mulai dibangun kios-kios atau toko untuk dapat meningkatkan perekonomian.

\section{Simpulan dan Saran}

\subsection{Simpulan}

Berdasarkan hasil penelitian dapat disimpulkan bahwa:

1. Sepanjang 14,5 km Jalan Raya Payangan, Kecamatan Payangan Kabupaten Gianyar terdapat 18 jenis tanaman peneduh sebagai pembentuk lansekap Jalan Raya Payangan. Sebanyak $12 \%$ dari total jumlah tanaman terdapat di Desa Melinggih Kelod, 20\% di Desa Melinggih, $47 \%$ di Desa Puhu dan 21\% terdapat di Desa Kerta.

2. Titik sebaran tanaman leci yang terdapat di sepanjang Jalan Raya Payangan, ditemukan sebanyak 42 pohon leci yang masih tumbuh dengan baik dan lima bekas tebangan pohon leci.

3. Berdasarkan acuan petunjuk teknis syarat tanaman untuk lansekap jalan ada sembilan, dari sembilan persyaratan tersebut tanaman leci hanya memenuhi lima persyaratan, dengan demikian tanaman leci tidak layak sebagai tanaman lansekap tepi jalan di Jalan Raya Payangan, Kecamatan Payangan Kabupaten Gianyar.

\subsection{Saran}

Berdasarkan simpulan dapat disarankan:

1. Menjaga kelestarian tanaman leci sebagai flora identitas Kabupaten Gianyar, sebaiknya pemerintahan daerah Kabupaten Gianyar membuat program wajib untuk peremajaan dan menambah populasi tanaman leci serta menentukan lahan yang khusus untuk menanam tanaman leci, seperti ruang-ruang publik milik desa di seluruh Kabupaten Gianyar.

2. Sebaiknya pemerintah daerah Kabupaten Gianyar membuat regulasi khusus yang membahas tentang tanaman leci dan memberikan penghargaan kepada masyarakat yang memiliki dan mempertahankan tanaman leci, sehingga dapat menjaga kelestarian tanaman leci sebagai flora identitas Kabupaten Gianyar.

3. Masyarakat Kecamatan Payangan hendaknya lebih memperhatikan kelestarian dan mempertahankan tanaman leci yang masih ada saat ini, karena tanaman leci merupakan flora identitas Kabupaten Gianyar dan sudah tergolong tumbuhan langka.

\section{Daftar Pustaka}

Carpenter, P.L., T.D. Walker, F.O. Lanphear. 2000. Plants in the Landscape. W.H. Freeman and Company, San Francisco. 476p.

Climate-data.org "Iklim: Payangan" Tersedia online: http://id.climatedata.org/ location/ 332310. Diakses 12 Desember 2016. 
Direktorat Jenderal Bina Marga - Departemen PU. 1996. Tata Cara Perencanaan Teknik Lansekap Jalan, No. 033/T/BM/1996, Maret 1996.

Dprd-gianyarkab.go.id. 2015. Flora Identitas Kabupaten Gianyar. Tersedia online: http://dprdgianyarkab.go.id/index.php/produk-hukum/peraturan-dprd/itemlist/date/2015. Diakses 24 Maret 2017.

Peni, Y. 2015. Identifikasi Dan Karakterisasi Sumber Daya Genetik Tanaman Buah-Buahan Lokal Di Kabupaten Gianyar. Skripsi. Denpasar: Program Studi Agroekoteknologi Fakultas Pertanian Universitas Udayana.

Phiets. 2009. Budidaya Leci. Tersedia online: https://phiets.wordpress.com/2009/06/06/ budidaya-leci/. Diakses 27 Mei 2016.

Profil Kecamatan Payangan, 2015. Kecamatan Payangan.

Runa, M. 2015. Dikutip dalam "Leci Bali". Online. http://www.kompasiana.com/ budiartha/ lecibali_55009265a33311376f5117e8. Diakses 24 Desember 2016

Silalahi, U. 2006. Metode Penelitian Sosial. Unpar Press. Bandung. $258 \mathrm{Hal}$.

Steenis, C.G.G.J. van. 2005. Flora. PT Pradnya Paramita. Jakarta. $431 \mathrm{Hal}$.

Sudjana, D. 2001. Metode Statistika. Tarsito. Bandung. 263 Hal.

Sugiyono. 2004. Metode Penelitian Bisnis. CV. Alfabeta. Bandung. $156 \mathrm{Hal}$. 